\begin{tabular}{|l|l|l||}
\hline \multicolumn{2}{|c|}{ PublisherInfo } \\
\hline \hline PublisherName & $:$ & BioMed Central \\
\hline \hline PublisherLocation & $:$ & London \\
\hline \hline PublisherImprintName & $:$ & BioMed Central \\
\hline \hline
\end{tabular}

\title{
NK T cells in rheumatoid arthritis
}

\begin{tabular}{||l|l|l||}
\hline \multicolumn{2}{|c||}{ ArticleInfo } \\
\hline \hline ArticleID & $:$ & 215 \\
\hline \hline ArticleDOI & $:$ & $10.1186 /$ ar-2000-66770 \\
\hline \hline ArticleCitationID & $:$ & 66770 \\
\hline \hline ArticleSequenceNumber & $:$ & 172 \\
\hline \hline ArticleCategory & $:$ & Paper Report \\
\hline ArticleFirstPage & $:$ & 1 \\
\hline \hline ArticleLastPage & $:$ & 4 \\
\hline \hline & $:$ & RegistrationDate : 2000-1-5 \\
ArticleHistory & $:$ & OnlineDate \\
\hline \hline ArticleCopyright $2000-1-5$ \\
\hline \hline ArticleGrants & $:$ & Current Science Ltd2000 \\
\hline \hline ArticleContext & $:$ & \\
\hline \hline
\end{tabular}




\section{Keywords}

CD161, natural killer T cell, NKR-P1, rheumatoid arthrtitis, Th1/Th2 imbalance

\section{Context}

In rheumatoid arthritis (RA), T helper (Th) 1 cells, which secrete interferon (IFN)-?, predominate over Th2 cells, which secrete interleukin (IL)-4, IL-5, IL-10 and IL-13. To date, neither the nature of the Th1 predominance nor the relevance to pathogenesis or disease course has been fully understood. Natural killer (NK) T cells have been suggested as a potential source of IL-4 for Th2 differentiation. NK T cells express unique NK cell markers in addition to T cell receptor (TCR)a?. In mice, NK T cells comprise $0.4 \%$ of a?-thymocytes but $5 \%$ of splenic $\mathrm{T}$ cells and $40 \%$ of bone marrow $\mathrm{T}$ cells. A large fraction of peripheral NK T cells is characterized by expression of the invariant Va14Ja281 TCRa in mice and Va24JaQ in humans (90\% homology at the amino acid level in the CDR3 region) and both have restricted TCR V? expression, suggesting the recognition of similar antigens. NK T cells recognize the MHC class I-like CD1d protein. The independent capacity of NK cells to secrete IL-4, in addition to IFN-?, has implicated them in the differentiation of naive T cells into Th2 cells. Interestingly, a more general role for NK T cells in autoimmune disease has been suggested since selective reduction of $\mathrm{Va}^{+} 4^{+} \mathrm{NK} \mathrm{T}$ cells has been associated with disease development in several autoimmunity-prone mice such as $\mathrm{C} 57 \mathrm{BL} / 6 \mathrm{lpr} / \mathrm{lpr}, \mathrm{C} 3 \mathrm{H}$ gld/gld or non-obese diabetic mice. Furthermore, in humans, a selective reduction of $\mathrm{Va}_{2} 4 \mathrm{JaQ}^{+} \mathrm{NK}$ T cells, which usually comprise $20-100 \%$ of $\mathrm{CD}^{-} \mathrm{CD}^{-} \mathrm{T}$ cells in healthy people, has been reported in patients with systemic sclerosis and diabetes mellitus type I. To assess the number of NK T cells in patients with RA compared to healthy controls, and any relation between number of NK T cells and activity or severity of the disease.

\section{Significant findings}

In patients with RA the number of NK T cells (25 ? 20/?1) and the number of $\mathrm{CD} 56^{+} \mathrm{CD}^{+}$cells $(60$ ? $46 / ? 1)$ was significantly reduced compared to healthy controls (143 ? 53/?1, $p<0.0001$, and 116 ? 54/?1, $p<0.0001$, respectively). In contrast, there was no difference in the number of conventional NK cells $\left(\mathrm{CD}^{+} 6^{+} \mathrm{CD}^{-}\right)$between RA patients and controls. Also, the ratio of NK T cells/NK cells (NKR$\mathrm{P} \mathrm{A}^{+} \mathrm{CD}^{+} / \mathrm{CD}^{+} 6^{+} \mathrm{CD}^{-}$) was significantly reduced in RA patients versus healthy controls. A weak 
correlation was found between the number of NK T cells and serum ?-globulin. No relevant influence of the various disease-modifying anti-rheumatic drugs on the number of NK T cells could be found.

\section{Comments}

The authors confirm previous data showing that conventional NK cells are not different in $R A$ patients and controls (Taylor et al, Scand J Rheumatol 1993, 22 :280-283 [ Abstract]; Thoen et al, Clin Rheumatol 1987, 6 :215-225). However, the finding of decreased NK T cells in RA is new and this merits further attention. Recent data suggests a differential regulation of cytokines by NK T cells in mice. When stimulated in vitro with anti-CD3, murine $N K 1.1^{+} \mathrm{CD} 4^{+} \mathrm{T}$ cells produce large amounts of IL-4 and IFN-?. In contrast, upon stimulation via CDI substantial amounts of IL-4 but little IFN-? are produced and NK1.1 may serve as a receptor leading to IFN-? production but not causing IL-4 production (Chen et al , J Immunol 1997, 159 :2240-2249). Therefore, a complex role in regulating immune responses has been suggested for NK T cells. The fact that in several autoimmunity-prone mice levels of $\mathrm{VaI}^{+}$cells are reduced during or shortly before disease onset (see above) is particularly intriguing. Along this line, the reduction of Va24JaQ ${ }^{+}$cells in systemic sclerosis (Sumida et al, J Exp Med 1995, 182 :1163-1168) and in diabetes type I (Wilson et al, Nature 1998, 391 :177-181) suggests a more general role of NK T cells in autoimmunity. Although we do not know with certainty that the NKR$\mathrm{PlA}^{+}$cells investigated in the present study are also Va24JaQ ${ }^{+}$this is likely to be the case. RA appears to be another autoimmune disease related to a change in this particular NK T cell subset.

\section{Methods}

Peripheral blood cells from 60 patients with RA and 36 healthy controls were immunostained using monoclonal antibodies directed against NKR-P1A (DX1), CD56 (Leu-19) and CD3 (Leu-4) and subsequently analysed by three-colour flow cytometry. The NK T cell population was defined as NKR$\mathrm{P}_{1 \mathrm{~A}^{+}} \mathrm{CD}^{+}$, and was distinguishable from conventional T cells (CD3 $\left.{ }^{+} \mathrm{CD} 56 \mathrm{NKR}-\mathrm{P} 1 \mathrm{~A}^{-}\right)$, NK cells $\left(\mathrm{CD}^{+} 6^{+} \mathrm{CD}^{-}{ }^{-}\right.$or NKR-P1A $\left.{ }^{+} \mathrm{CD}^{-}\right)$and $\mathrm{CD}^{-} 6^{+} \mathrm{CD}^{+}$cells (T cells with the NK marker). 


\section{References}

1. Yanagihara Y, Shiozawa K, Takai M, Kyogoku M, Shiozawa S: Natural killer (NK) T cells are significantly decreased in the peripheral blood of patients with rheumatoid arthritis (RA). Clin Exp Immunol . 2000, 118: 131-136.

This PDF file was created after publication. 